Richter, Ernst (Halle-a-S.) - Die nicht perforironde cilernde Entzïndung dè Siebenhiblin unit ihre oferative Behandlung. (The Non-Perforating Purulent Infammation of the Frontal Sinus, and its Tratment). Inaugural Dissertation. Leipsic, 1895 .

Goon review of the literature and the present position of the treatment of the disease. The author adds seven cases treated in Habermann's clinic in Graz. All cases have improvel or been cured.

Michacl.

Gussenbauer (Vienna). - Tenporary' Resection of the Nose for Entrance into the Frontal Sinus, the Ethmoid and Orbital Caritics. "Wiener Klin. Woch.," I895, No. 21 .

Tre author has in two cases removed malignant neoplasms of the ethmoidal region and extending round the circumference hy temporary resection of the nose. Both patients have been cured. The details are of surgical interest. Michatl.

Czerny (Heidellerg). - Osteoplastic Ofoning of the Frontal Sinus. "Langenbeck's Archiv," Band 50 , lleft 3 .

Tre author recommends not to remove the anterior osseous wall of the frontal sinus, but merely to dislocate it, and to close with it the sinus after the cure of the empyema. He performed this operation twice with good result.

Michael.

Hessler (Malle-a-S.).-Operation for Adensid Vegetations with the New Pharyngotome of Schutz. "Minchener Med. Woch.," 1895, No. 24.

RECOMMENIATION of the instrument.

Michael.

Fouchier, A. A.-A Few Modifications in the Operating Process of Adenoid Tumours, "Arch. of Ophthal, and Otol.," April, IS95.

A Descrimtion of a combined tongue depressor and mouth-gag, and a modified Hicguet-Munger's curette, the handle of the latter being at a right angle to the shaft, and with a Gottstein's blade instead of a ring knife.

R. Lake.

Hamilton, H. B.-Some Interesting Conditions attending Post-Nasal Growths. "Montreal Med. Journ.," Aug., I895.

The first was a case complicated with rhinitis, and giving rise to asthma, which was cured by treatment of the rhinitis and removal of the growths; the other a case of ethmoidal disease caused by a similar condition and relieved by treatment of the rhinitis.

R. Lake.

\title{
NECK，THYROID， \&G.
}

\section{Notkin (Kiew).-Contrilution to the Physiology of the Thyroid Gland. "Wiener} Med. Woch.," I895, Nos. 19 and 20.

THE author has produced a proteid from the thyroid gland which he calls thyrotoxin. By injection of this proteid into animals he produced all symptoms of cachexia strumipriva. He concludes from his experiments that the thyro-colloid is not a secretion of the thyroid gland, but a secretion of the whole body. The thyro-proteid is the poison which intoxicates the organism in cases of cachexia strumipriva. The function of the thyroicl gland is the purification of the body from thyro-proteid. The gland removes it from the body along with its toxic power. It is probable that Basedow's discase will be successfully treated by application of thyro-proteid.

Michael. 
Scherk (Hamburg), - The Function of the Thyroid Gland. "Acrtic Rund:chau," 1895, Nio. 25.

REVIEW.

Michael.

Revillod (Ceneva). - On Thyroidismus. Schweizer Acrzic in Launane, Ileeting, May 4,1895 .

Two groups of symptoms are chiefly caused ly anomalie of the secretion of the thyroid gland-myxnedema and Basedow's disease. 'The latter i; profucul by excess of secretion; the former by decrease of secretion. $.1 l_{x}$, (nn the sulhance of the bones the Basedow (Graves) disease has an influence. as well as uyon diuresis, Cod liver oil is a good medicament for the symptoms of Based $\cdots$ : rlineare.

Morix (Colombier): Much in this question is not yet clar. It in curious that in some cases the symptoms of Basedow's disease are influenced for sow liy the use of thyroid gland. The author hats observed some fumilien in which these

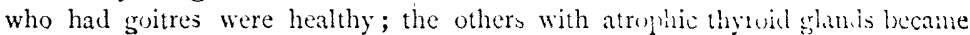
tuberculous.

GIRARD (Berne) also has made investigations on the reiation between groitres and tuberculosis which were first observed in the first guarter of this century, and has found that malignant tumours (excluding struma maligna) are obsesed three lines more frequently in strumous than in non-strumous persons. Tulveruluni. i; three times more frequent in non-strumous than in strumous jurrons. As to chesale of the heart, there exists no difference. Fracures of the bone, are much more frequent in strumous persons. Traumata are equally olsecteet in struments and in non-strumous persons.

Ml:kai:

Eulenburg (Berlin).-Abuse of Thyroid Talluids. "Deutsche Mel. Wuch.," I895, No. 32.

For lipomatosis, since Leichtenstern's pullication, these salioid, have leen often used by patients without medical advice. Their employment is often follower liy severe nervous symptoms. The sale of thyroid in tabluils without rutricition should not be allowed.

Nichae:

Grube (Neuenahr), - Etiolosy of Basedow's Disease, "Neurrol. Cintralbl.," Nay, I894.

THE author believes that the disease is caused by auto-intosication. Whichael.

Pel P. K. (Amsterdam). - Myxadema. "Volkmann's Vortriige," Ileft, No. I23. Review and photographic reproductions of two cases of myxedema treated ly the author with thyroid gland with good results.

.Tichael.

Lichtwitz (Bordeaux).-Branchial Fistula in the Ncis curcl by Elistrolysis. "Arch. d'Electricité MÉdicale," April I5, I895.

THE fistular orifice was situated about two centimetres to the left of the mildle line between the hyoid bone and thyroid cartilage. A whalebone prole was passed upwards and inwards to the right for six and a half centimitres hehind the great cornu of the hyoid, and could be felt by the patient at the level of the right tonsil. Treatment was called for on account of the discharge, which involved the continuous wearing of a dressing, but cutting operations were refurel. Electrolysis was carried out by means of a fine electrode one millimetre in diancier, and covered with caoutchouc to within two centimètres of its extremity. This was attached to the negative pole, and after cocainization, currents of from two to three milliampères were tolerated. Seventeen applications were maic at intervals of from a weck to a fortnight. The fistula was thei closed, and at the end of con months still continued so.

I. undas Giant. 
Kopfstein (Prague).-On a Lateral Air. Tumour of the Neck covered with Cylindrical Epithelium. "Wiener Klin. Rundschau," 1895, Nos. 27 and 28.

A patient, twenty-nine years old, remarked that during blowing and snuffling an elastic tumour appeared under the left half of the lower jaw. On pressure the tumour disappeared. The tumour enlarged while the patient was at work, and disappeared during rest. Operation was performed consisting of the exturpation of a sac with thin blue walls. When it was opened air was discharged. The extirpated tumour was eight centimetres long. The internal surface was covered with ciliated epithelium. The author believes that it originated from an incom. pletely closed branchial cyst.

Michael.

\section{E A R S.}

Lester, J. C.-In Elitric Pressure Sound for the Direct Vibration of the Membrana Tympani. "New York Med. Journ.,"June 8, i895.

A DESCRIPTION (illustrated) of the instrument and motor vibrations of from five hundred to fifteen hundred a minute, and with an amplitude of from zero to half an inch, are obtainable. The motor is held in one hand and the sound in the other. It is easy of application, causes little reaction, and is of especial value in sclerotic and atrophic conditions.

R. Lake.

Marple, W. B.-Successful Mechanical Treatment of some unusual Aural Conditions. "New York Med. Journ.," June I, I\$95.

TuE writer refers to Blake's method by a strip of rubber to exert pressure on the malleus. The first patient, whose hearing distance in the right ear was one foot, complained of vertigo in that ear when the head was tilted to that side. Blake's rubber strip was applied eventually with excellent results, but subsequently exchanged for a disc of paper, which completed a cure. In the two remaining cases a particular note caused a loud noise in the ear; one was cured with the spring alone, and the other by the spring followed by the disc. An explanation of these buzzings is afforded by Helmholz, who attributes it to the cog-like articulation between the incus and malleus, the former, in any excessive outward movement, leaving the latter behind, and being struck by the returning hammer. The writer attributes an undue prominence of these sounds to a laxness of the ligaments of the articulation, the spring tightening up the joint, and the vertigo in the first case to an abnormal laxness of the articulations in the chain of ossicles.

R. Lake.

Hefleblower, E. C.-Clonic Spasm of the Tensor Tympani. "New York Med. Journ.," March 16, I895.

Previously reported cases are quoted by the author, who then adds the two following cases from his own practice:-(I) A woman, thirty-five years of age, had suffered from a clicking noise in the ears in conjunction with a twitching of the muscles of the throat. Exertion and fright made it worse ; rest and quiet relieved it. In the left ear a perceptible indrawing of the membrane was seen at every click. The palate was affected, but not the larynx. The patient's father was insane. In the secont, a man of mature age, the noise was louder; heard at two feet away; both the palate and larynx were affected. This patient was nearly insane. The author draws attention to the question of mental affections in relation to the disorder under consideration. IIe next reviews most minutely the 